\section{COMMON WILD FLOWERS CONSIDERED IN RELATION TO INSECTS * \\ II.}

THE Common Heaths (Erica tetralix and E. cinerea) offer us another very ingenious arrangement. In $E$. tetralix (the Cross-leaved Heath), for instance, the flower is in the form of a bell (Fig. I5), which hangs with its mouth downwards, and is almost closed by the pistil $(s t)$, which represents the clapper. The stamens are eight in number, and each terminates in two cells, which diverge slightly, and have at their lower end an oval opening. But though this opening is at the lower end of the anther cells the pollen cannot fall out, because each cell, just where the opening is situated, touches the next anther cell, and the series of anthers thus form a circle surrounding the pistil and not far from the centre of the bell. Each anther cell also sends out a long process, which thus forms a series of spokes, standing out from the circle of anthers. Under these circumstances, a bee endeavouring to suck the honey from the nectary cannot fail firstly to bring its head in contact with the viscid stigma, and thus to deposit upon it any pollen derived from a previous visit; and secondly, in thrusting its proboscis up the bell, it inevitably comes in contact with one of the anther processes, which acts like a lever and dislocates the whole chain of anther cells when a shower of pollen falls from the open anther cells on to the heail of the bee. '

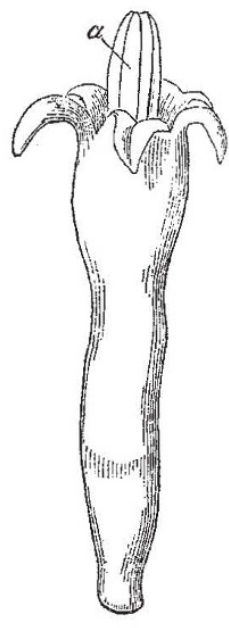

F1G. I5.

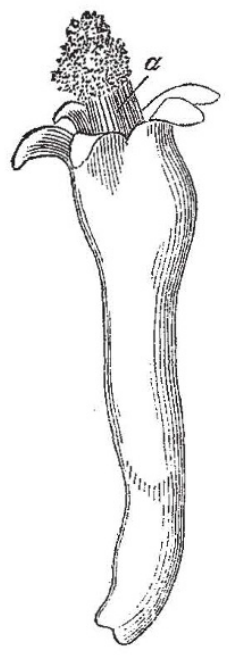

Fig. 16.

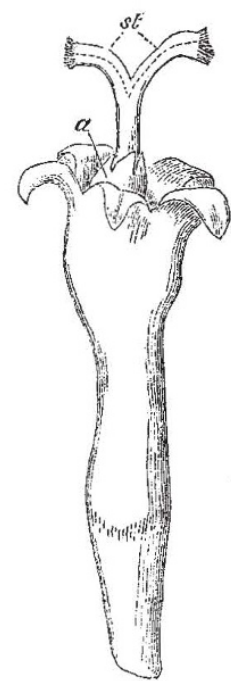

FIG. I7.
In the allied genus Vaccinium there is a similar arrangement, but the anther cells are closed, not by touching one another, but by resting against the style, so that the style itself closes the openings until the anthers are distributed by the proboscis of the bee. V. uliginosum is much larger than $V$. myrtillus, and consequently more conspicuous ; $V$. myrtillus, on the other hand, has the compensating advantage of being richer in honey.

The genus Arbutus also is said to agree in essentials with Vaccinium.

In many cases the effect of the colouring and scent is greatly enhanced by the association of several flowers on one branch or raceme, as, for instance, in the Wild Hyacinth, the Lilac, and othe rfamiliar instances. In the great family of Umbelliferæ this arrangement is still further taken advantage of, as in the common Wild Chervil (Cherophyllum sylvestre).

In this group the honey is not, as in the flowers just described, situated at the bottom of a tube, but lies exposed, and is therefore accessible to a great variety of small insects. The union of the florets into a head is, moreover, not only of advantage in rendering them more conspicuous, but also effects a considerable saving of time, as it enables the insects to visit a given number of insects more rapidly, and consequently renders their fertilisation more certain than if they had stood singly.

The self-fertilisation which, in small flowers such as these,

$$
\text { * Continued from } p_{\mathrm{s}} \text { 4o }
$$

t Popular Science Reviezv, April 1870. would otherwise naturally occur, is provided against by the fact that the fowers are generally proterandrous, that is to say, the stamens ripen before the pistil, and the latter is not mature until the former have shed their pollen. In some cases, as, for instance, in Myrrhis, the flowers of one head are all firstly in the male condition, and subsequently in that with mature stigmas, none of them arriving at the second stage until they have all passed through the first.

In Cherophyllum the petals are not symmetrical, the outer ones being considerably larger than the others, and in many umbellifers the florets themselves on the outer edge of the bunch or umbel are considerably larger than the inner ones.

This distinction is carried still further in the Compositæ, where

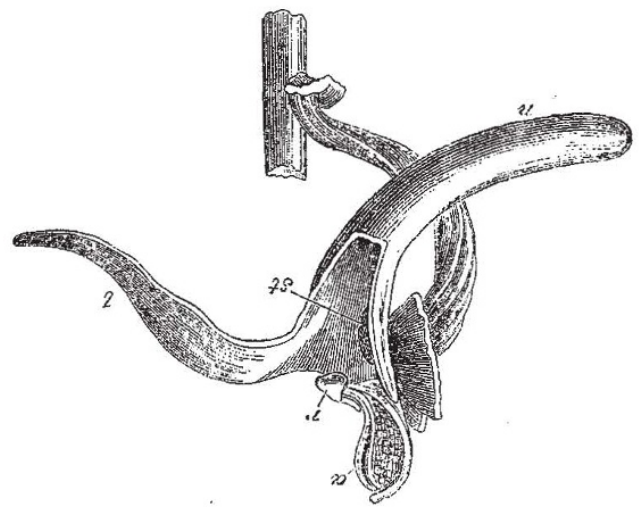

Fig. $x 8$.

also the florets are so closely packed together that the whole umbel is commonly, though of course incorrectly, spoken of as a flower.

For instance, the heads of the common Daisy, as I need hardly mention, are not strictly speaking flowers, but bunches of flowers closely packed together on a common base or receptacle.

The advantages of this arrangement are :-

r. That the flowers become much more conspicuous than would be the case if they were arranged singly.

2. That the facility with which the honey is obtained renders then more attractive to insects.

3. That the visits of the insects are more likely to be effectual,

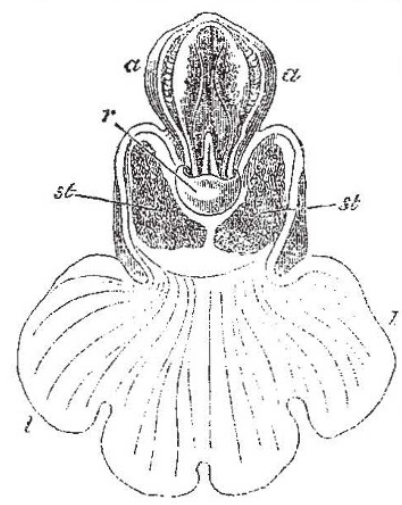

Fic. Ig.

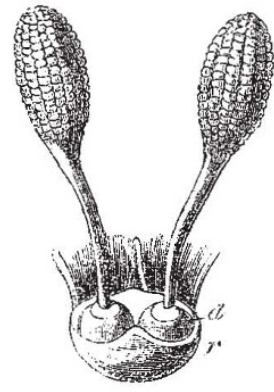

FIG. 20. since the chances are that an insect which onve aliglits, touches several, if not many, florets.

No wonder, therefore, that the Composite are the most extensive family among flowering plants, are represented in every quarter of the gloive and in every description of station, ${ }^{*}$ and contain nearly ien thousand species.

If we take, for example, the common Feverlew, or large white Daisy (C/urysanthemum parthonimm), which has been well described by Dr. Ogle, $\uparrow$ ine flower-heads consist of an outer row of female florets, in which the tubular corolla terminates on the outer side in a white leaf or ray, which doubtless

* Eentham, "Handlook of the British Flora," vol. i. p. 408 ; Jour. Limn. Soc. 1873, p. 3,35 .

+ Popzlar Satence Reviezu, April 1870 
is useful in making the flower conspicuous. The inner florets are also tubular, but are small, yellow, and without rays. Each of these florets is furnished with stamens as well as a pistil. The stamens are united on their inner sides so as to form a closed tube, within which the pistil lies. They ripen before the pistil, and dehisce on their inner sides, so that the pollen is discharged into the upper end of the tube above the head of the pistil. When the flower opens the pollen is already ripe, and fills the upper part of the stamen tube. A floret in this condition is represented in Fig. 15. The pistil, however, also continues to elongate, and at length pushes the pollen against the upper end of the tube, which gives way, and thus the pollen is forced out of the tube, as shown in Fig. 16 . The pistil itself terminates in two branches, which at first are pressed closely to one another, and each of which terminates in a brush of hairs (Fig. I7). As the style elongates this brush of hairs sweeps the pollen cleanly out of the tube, and it is then removed by insects. When the pistil

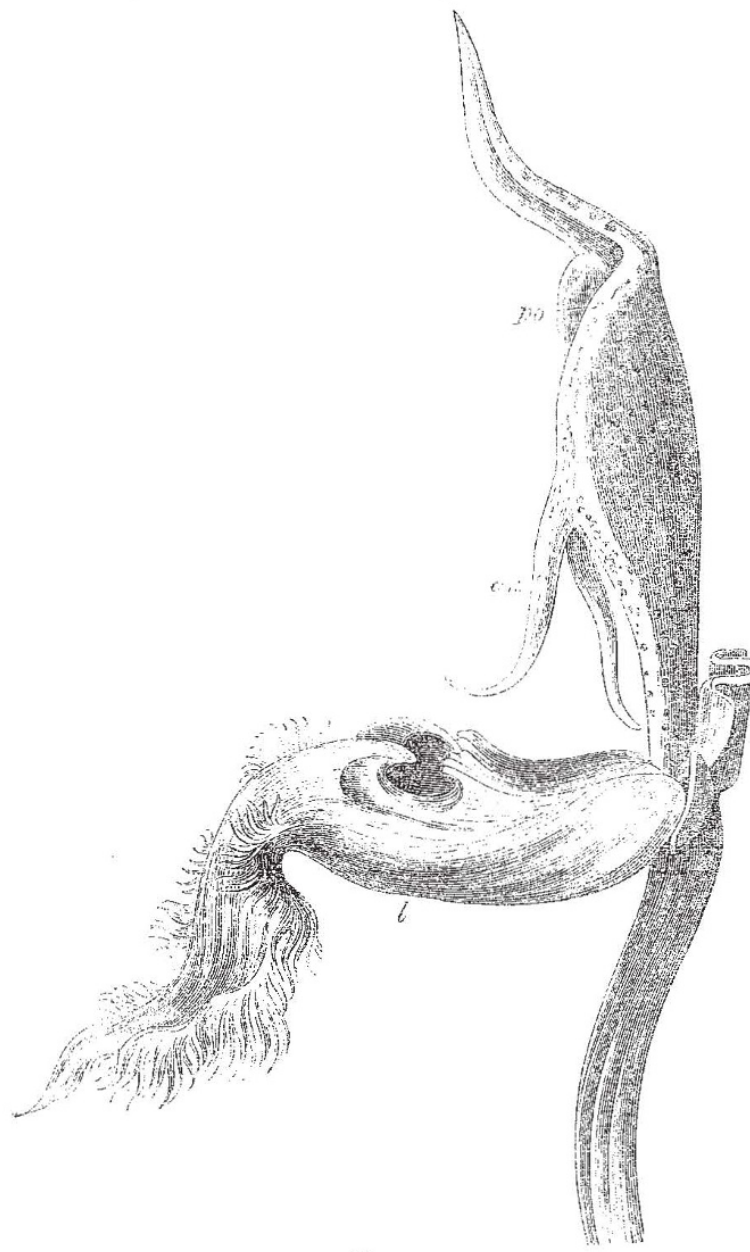

FIG. 2I.

has attained its full length two branches open and curve downwards so as to expose the stigmatic surfaces (Fig. I7, st) which had previously been pressed closely to one another, and thus protected from the action of the pollen. From this arrangement it is obvious that any insect alighting on the flower-head of ment it is obvious that any insect alighting on the with the pollex of the younger flowers, which then could not fail to be brought into contact with the stigmatic surfaces of the older ones. As the expansion of the flowers begins at the outside and thence extends to the centre, it is plain that the pollen of any given floret can not be used to fertilise one situated on its inner side. Consequently, if the outer row of florets produced pollen, it would, in the great majority of cases, be wasted. I have, however, already mentioned that these florets do not produce pollen, while the saving thus effected enables them to produce a larger corolla. It is also interesting to observe that in these outer flowers the branches of the pistil do not possess the terminal brush of hairs which, in the absence of pollen, would be useless.

In other Composite, as in the Marigold, while the ray flower produce no pollen, the disc flowers develop stigmas only. In this case, as in the Feverfew, the pistil of the ray flowers does not require or possess the texminal brushes of hairs, as there is no pollen to be swept out. The central flowers, on the otber band, though they develope no stigmas, require a pistil in order to force the pollen out of the anther tube. Hence the pistil is pri: sent as usual, but the head is simple and not bifid. This compilete alteration of the function of the pistil is extremely curious

Perhaps no group of fotwers offers rore remarkalile adapta. tions than the orchids, which have been so admirably d scribed by Mr. Darwin." As an illustration of our English speciss, I shall take the common early purple orchis (Orchis masculdi), as being one of the commonest, if not the commonest, species; and a fair example of some of the remainder, which however differs in many interesting and important points.

Fig. I8 represents the side view of a flower, from which all the petals and sepals have been removed, except the labellum ( $l)$, half of which has been cut away, as well as the tipper portion of the near side of the nectary (n2). The pollen forms two masses (Fig. I9, a a), each attached to a tapering stalk, which gives the whole an elongated pear-like form, and is attached to a round sticky disk $(d)$, which lies loosely in a cap-shaped envelope or rostellum $(r)$. This envelope is at first continuous, but the slightest touch causes it to rupture transversely, and thus to expose the two viscid balls (Fig. 20, d). Now suppose an insect. visiting this flower; it alights on the labellum, and pushing its proboscis down the nectary to the honey, it can hardly fail to bring the base of the proboscis into contact with the two viscid discs, which at once adhere to it, so that when the insect draws back its proboscis, it carries away the two pollex masses. It is easy to imitate this with a piece of grass, and to carry away on it the two pollen masses and their stalks. If, however, the pollinium retained this erect position when the insect came to the next flower, it would simply be pushed into or against its old position. Instead however of remaining tipright, the pollinia, by the con. traction of the minute disc of membrane to which they are attached, gradually tum downwards and forwards, and thus when the insect sucks the next llower, the thick end of the club exactly strikes the stigmatic stuface $(s t)$. The pollinium or pollen mass consists of packets of pollen grains, fastened togetber by elastic threads. The stigma, however, is so viscid, that it pulls off some of these packets, and ruptures the threads, without re. moving the whole pollinium; so that one pollinium can fertilisc several flowers.

I cannot resist mentioning the case of Cataselim, one of the Vaudræ, which, as Mr. Darwin says, "are the most remarkable of all orchids." In Catasetum (Fig. 21) the pollinia and the stigmatio surfaces are in different flowers, hence it is certain that the formet must be carried to the latter by the agency of insects. The pollinia, moreover, are furnished with a viscid dise, as in orchis, but from the large size of the flower, and the position of the honey, the insect has no inducement to approach, and in fact does not touch, the viscid disc. The flower, however, is endowed with a peculiar sensitiveness, and actually throws the pollinium at the insect. Mr. Darwin has been so good as to irritate one of these flowers in my presence: the pollinium was thrown nearly $3 \mathrm{ft}$., when it struck and adhered to the pane of a window. This irritability, however, is confined to certain parts of the flower of Catasetum saccatum, which is also shown in section in Fig. 22. In this figure it will be seen that the pollinium $(d p)$ is curved, and in a state of considerable tension, but retained in that position by a delicate membrane. Now, insects alight as usual on the labellum of the flower $(l)$, and it will be seen that in front of it are two long processes, or antenna $(a n)$. In some species of Catasetum both these antennee are highly irritable; in the present species the right-hand one is apparently functionless; but the moment the insect touches the left-hand one, the excitement is conveyed along it, the membrane retaining the pollinium is ruptured, and the latter is immediately jerked out of the flower by its own elasticity, with considerable force, with the viscid disc foremost, and in such a direction as to come in contact with the head of the insect which had touched the antenna.

I will only mention one other tropical flower, the very curions Marcgravia nepenthoides, described by Mr. Belt in his interesting work, "The Naturalist in Nicaragua." The flowers are disposed in a circle, and beneath them are suspended some 
pitcher-like vessels, which secrete a sweetish liquid, and thus attract numerous insects. These again bring birds, which can hardly fail to brush against the flowers, and thus convey the pollen from one to the other.

In the flowers hitherto described, while the several species offer the most diverse arrangements, we have met with no diffe. rences within the limits of the same species, excepting those dependent upon sex. I must now call attention to some cases in which the same species possesses flowers of two or more kinds, which sometimes, as in the Violet, are adapted to different conditions ; but more frequently are so constituted as to ensure cross-fertilisation.

In some of the violets ( $V$. odorata, canina, \&c.), besides the blue flowers with which we are all so familiar, but which produce very little seed, there are other autumnal flowers, almost without petals and stamens, and which indeed have none of the appearance of true flowers, but in which the seeds are produced. As these curious flowers, however, have no relation to our present subject, I shall not now dwell on them.

I pass on to the genus Primula, which offers a most interesting case of dimorphism, The Cowslip and Primrose resemble one another in many respects, though the honey they secrete must be

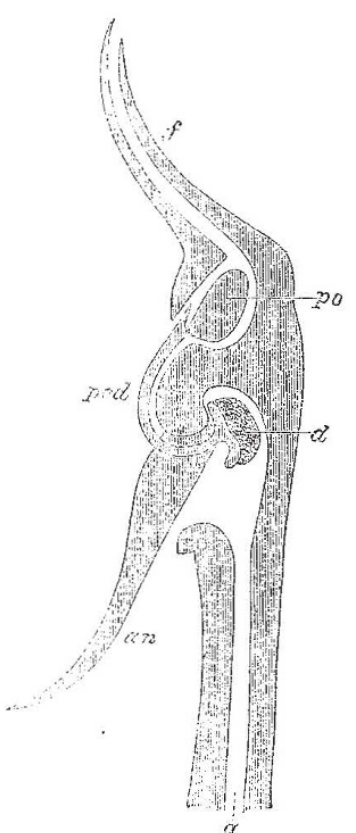

Y
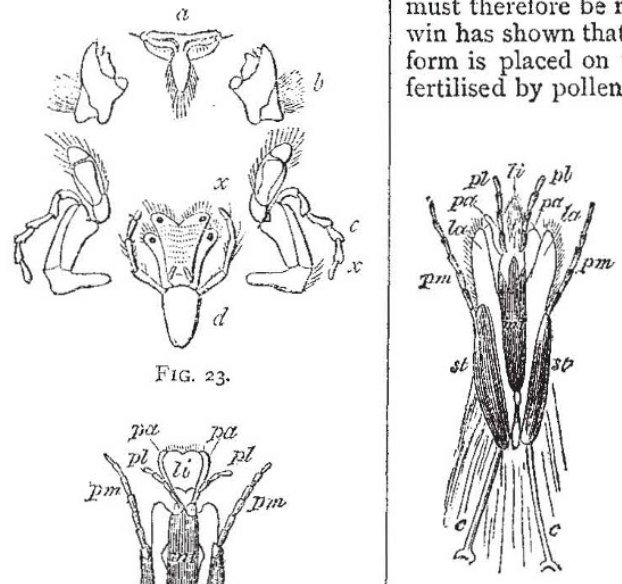

FIG. 27.

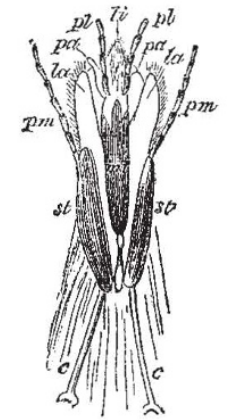$$
\text { FIG. } 27
$$
to be. dimorphic, but not all.*

another: for instance, the stigma of the long-styled form is globular and rough, while that of the short-styled is smoother, and somewhat depressed. The pollen of the two forms is also dissimilar, that of the long-styled being considerably smaller than the other, 7-700oths of an inch in diameter against $\frac{10--11}{7000}$ or nearly in the proportion of three to two; a difference the im-

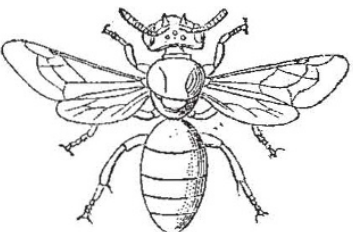

FIG, 25.

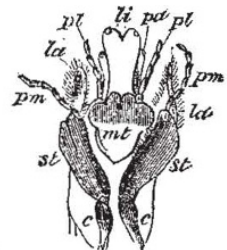

Fig. 25.

portance of which is obvious, for each has to give rise to a tube which penetrates the whole length of the style, from the stigma to the base of the flower, and the tube in the long-styled form must therefore be nearly twice as long as in the other. $\mathrm{Mr}$. Darwin has shown that much more seed is set if pollen from the one form is placed on the pistil of the other, than if the flower is fertilised by pollen of the same form, even if taken from a dif.

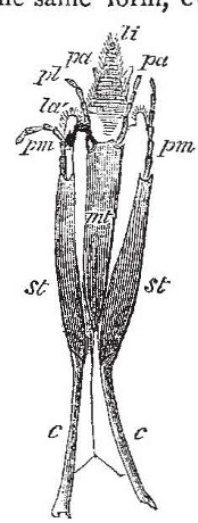

Fig. 28.

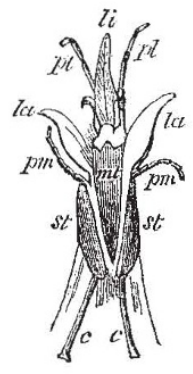

FIG. 29.

ferent plant. Nay, what is most remarkable, such unions in Primula are more sterile than crosses between distinct, though nearly allied species of plants, have in some cases been found

The majority of species of the genus Pximula appear to be

Mr. Darwin has pointed out + that several species of Linium

FIG. 22 .

Fici, 24 .

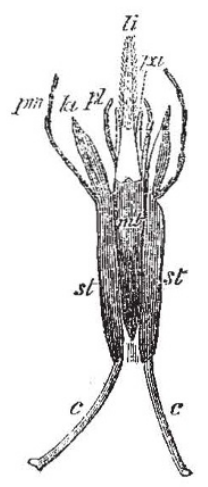

FIG. 30.

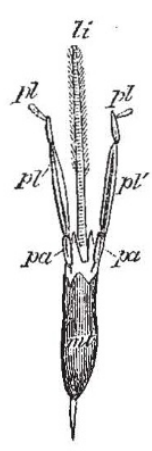

F1G: 3 r.

very different, for while the Cowslip is habitually visited during the day by humble bees, this is not the case with the Primrose, which, in Mr. Darwin's opinion, is fertilised almost exclusively by moths. (Jour. Linn. Soc., vol. x. p. 438.) This, however, is a digression.

Corresponding differences occur in the Polyanthus and Auricula and had long been known to gardeners, and even to school children (by whom the two kinds of flowers are known as "pineyed" and "thumb-eyed "), but it was reserved for the genius and perseverance of Mr. Darwin, to explain* the significance of this curious phenomenon, and the important part it plays in the economy of the flower. Now that Mr. Darwin has pointed this out it is sufficiently obvious : an insect thrusting its proboscis down a primrose of the long-styled form would dust its proboscis apart, which, when it visited a short-styled flower would come just opposite the head of the pistil, and could not fail to deposit some of the pollen on the stigma. Conversely an insect visiting a short-styled plant would dust its proboscis at a part further from the tip, and which, when it subsequently visited a longstyled flower, would again come just opposite to the head of the pistil. Hence we see that by this beautiful arrangement insects will carry the pollen of the long-styled form to the short-styled, and cice versâ.

There are other points in which the two forms differ from one * Einnear Foumal, 1862, p. 77.

are dimorphic in the same manner as the Cowslip and Primrose. Lythrum salicaria, however, $¥$ is even more remarkable, since as was remarked by Vaucher, but first explained by $\mathrm{Mr}$. Darwin, it presents us with three distinct forms (each contain-

* Scott, Proc. Linn. Soc., vol. viii., 1864, p. 80.

+ Jour. Linn. Soc., 1863 , p. 69

\pm Linn. Jour. $\$ 864$, p. $\$ 69$. 
ing a pistil and two groups of stamens), which he calls, from the relative lengths of their pistils, the long-styled, mid-styled, and short-styled. In this species, also, it is remarkable that the seeds of the three forms differ from one another, Ioo of the long. styled seeds being equal to I 2 I nid-styled or 142 short-styled. The pollen grains also not only differ in size (the long stamens having the largest-sized pollen grains, the middle-sized stamens middlesized pollen grains, and the short stamens small pollen grains), but also in colour, being green in the longer stamens, and yellow in the shorter ones; while the filaments are pink in the long stamens, uncoloured in the shorter ones. Mr. Darwin has also proved by experiment that this species does not set its seeds, if the visits of insects ares prevented; in a state of nature, however, the plant is much frequented by bees, humble-bees, and flies, which always alight on the upper side of the flowers in the stamens and pistil.

He has also shown that in this species, as in Primula, perfect fertility can only be obtained by fertilising each form with pollen from stamens of corresponding length. This case is indeed most complex, as the pollen of each set of stamens, when applied to the same stigma, acts most differently, and it would appear that the greater the inequality in length between the pistil and stamens, the greater the sterility.

The genus Lythrum is also remarkable for the great differences existing between different species. $L$. grafferi, like $L$. salicaria, is trimorphic; while $L$. thymifolia is dimorphic; and L. hysso. pifolia is homomorphic.

Let us consider the manner in which the bees are adapted to the flowers. Although we may in one respect say that the general organisation of the insect is modified with reference to these

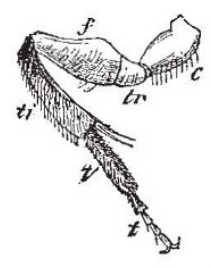

FIG. 32 .

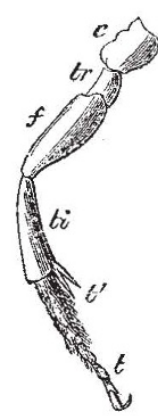

FIG. 33 .

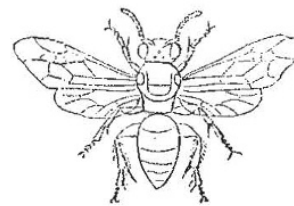

FIG. 34. relations, still, as Muller, from whom the following facts are mainly taken, has well shown, the parts which have been the most profoundly modified are the mouth and the legs. If we are asked why we assume that in this case the mouth-parts and legs have been modified, the answer is that they depart greatly from the type found in allied insects, and that between this type and these modified examples various gradations are to be found.

The mouth of an insect, say of a wasp (Fig. 23), is composed of (I) an upper lip, $a,(2)$ an underlip, $d$, (3) a pair of antexior jaws or mandibles, $b$, and (4) a pair of posterior jaws or maxillæ, $c$. These two pairs of jaws work laterally, that is to say, from side to side, and not as in man and other mammalia, from above to below. The lower lip and maxille are each provided with a pair of feelers or palpi $(c$ and $d, x)$. The above figures represent the mouth-parts of a wasp, in which, as is very usually the case, the mandibles are hard and horny, while the maxillæ are more delicate and membranous. In the different groups of insects these organs present, however, almost infinite variations.

Fig. 24 represents the mouth-parts of a bee, Prosopis (Fig. 25) The bees belonging to this genus construct their cells in sand, or in dry bramble sticks, lining them with a transparent mucus, which they smooth down with their trowel-like lower lip and which hardens into a thin membrane. That the mouth of Prosopis probably represents the condition of that of the ancestors of the hive-bees before their mouthparts underwent special modifications, may be inferred from the fact that the same type occurs in other allied groups, as is shown in Fig. 26, which represents the mouth of a wasp (Polistes), also seen from below.

We may therefore consider that Prosopis shows us special adaptation for the acquirement of honey, and in fact though the bees belonging to this genus feed their young on honey and pollen, they can only get the former from those flowers in which it is on the surface. In Andrena (Fig. 27), Halictus (Fig. 28), Panurgus (Fig. 29), Halictoides (Fig. 30), and Chelostoma (Fig. $3 \mathrm{r}$ ), we see various stages in the elongation of the lower lip until at length it reaches the remarkable and extreme form which it now presents in the hive- and humble-bees, and which enable them to extract the honey from most of our wild flowers, though no bees have the proboscis so much elongated as is the case with some butterflies and moths; perhaps as Hermann Muiller has

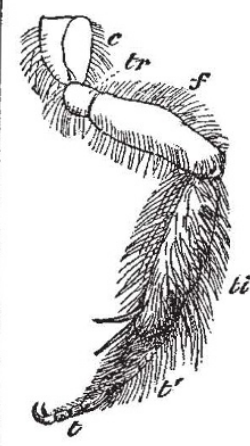

FiG. 35 .

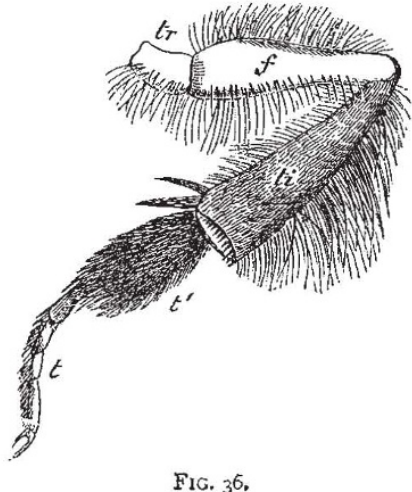

FIG. ${ }_{36}$. suggested, because the necessity of using their mouths for certain domestic purposes has limited its specialisation in this particular direction.

There are several flowers which are inaccessible to hive-bees, and to Bombus terrestris, which has a shorter proboscis than some of the other species belonging to that genus. Hermann Muiller mentions, for instance, that he has often seen Bombus terrestris endeavouring, in vain, to suck the flowers of the Oxlip (Primula elatior). Having satisfied themselves that they were unable to do so, but not till then, they proceeded to cut a hole in the base of the tube, and thus arrived at the honey. This seems to show, he observes, that they act upon the results of experience, and not by what is called mere instinct. Indeed any one who has watched bees in greenhouses will see that they are neither confined by original instinct to special flowers, nor do they visit all flowers indifferently. Müller mentions several cases in which he has seen honeyless flowers visited by insects; Genista tinctoria, for instance, is frequently visited by insects in search of honey although it does not contain any.

Certain insects, on the other hand, confine themselves to particular flowers. Thus, according to H. Miiller, Andrena florea visits exclusively Bryonia dioica, Halictoides $\quad, \quad, \quad$ species of Campanula, Andrena hattorfiana ", ", ", Scabiosa arrensis, Cilissa melauara ", ", Lytterum salicaria, Macropis labiata $\quad ", \quad$ ", Ly'simachia vnllgaris, Osmia adunca ", ", Echium.

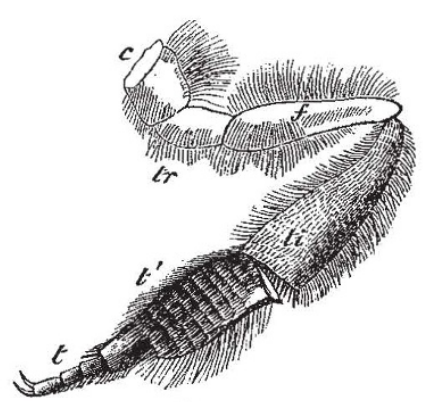

FIG. 37.

It would also appear that individual bees differ somewhat in their mode of treating flowers. Some humble bees suck the honey of the French Bean and the Scarlet Runner in the legitimate manner, while others cut a hole in the tube and thus reach it surreptitiously; and Dr. Ogle has observed that when he followed any particular bee she always proceeded in the same manner; some always entering by the mouth, others always cutting a hole. He particularly mentions that this was the case with bees of one and the same species, and infers, therefore, that 
they differ from one another in their degrees of intelligence; and his observations, though of course not conclusive, are interesting and suggestive.

If again we examine the hind legs of bees, we shall find similar gradations. In Prosopis (Fig. 32) they do not differ materially from those of genera which supply their young with animal food. Portions of the leg, indeed, bear stiff hairs, the original use of which probably was to clean this burrowing insect from particles of sand and earth, but which in Prosopis assist also in the collection of pollen.

Fig. 33 represents the hind leg of Sphecodes (Fig. 34), a genus in which the tongue resembles in form that of Halictus. Here we see the hairs deciderly more developed, a modification which has advanced still further in Halictus (Fig 35 ), in which we see that the development of the hairs is most marked on those segments of the hind legs which are most conveniently situated for the collection and transport of pollen.

In Panurgus the same change is still more marked, and the pollen-bearing apparatus is confined to the tit and first segment of the tarsus, a differentiation which is even more apparent in Anthophora. In these bees the pollen is simply entangled in the hairs of the leg as in a brush, but there are other genera, as for instance the humble bees and the hive bee, which moisten the pollen with honey, and thus form it into a sticky mass, which is much more easy to carry, and is borne, not round the leg, but on one side of it. In the humble bee (Bombus, Fig. 36), for instance, the honey is borne on the outer side of the hinder tibiæ, which are flattened, smoothed, and bordered by a row of stiff curved hairs, which thus constitute it $\mathrm{a}^{3}$ sort of little basket. Lastly, in the hive bee (Fig. 37), the adaptation is still more complete, the hairs on the first tarsal segment are no longer scattered, but are arranged in regular rows ; and the tibial spurs inherited by Bombus from far-distant ancestors have entirely disappeared.

In some bees the pollen is collected on the body, and here also we find a remarkable gradation from Prosopis, which has only minute and simple hairs, like a wasp; through Sphecorles, a Nomada, in which the longer hairs are still few, and generally simple, though some few are feathered; to Andrena and Halictus, where the hairs are much more developed; a change which is more marked in Sarapoda, Colletes, and Megachile; still more so in Osmia and Anthophora ; until we come to the humble bees, in which the whole body is covered with long feathered hairs.

Although flowers present us with all these beautiful and complex contrivances, whereby the transfer of pollen from flower to fower is provided for and waste is prevented, yet they are imperfect, or at least not yet perfect, in their adaptations. Many small insects obtain access to flowers and rob them of their contents. Malva rotundifolia can be, and often is, sucked by bees from the outside, in which case the flower derives no advantage from the visit of the insect. In Medicago sativa, also, insects can suck the honey without effecting fertilisation, and the same flower continues to secrete honey after fertilisation has taken place, and when apparently it can no longer be of any use. Fritz Miiller has observed that, though Posoqueric fragrans is exclusively fertilised by night-flying insects, many of the flowers open in the day, and consequently remain sterile.

It is of course possible that these cases may be explained away; nevertheless, as both insects and flowers are continually altering in their structure and in their geographical distribution, we should necessarily expect to find such instances. Animals and plants constantly tend to adapt themselves to their conditions, just as water tends to find its own level.

I have been good-humouredly accused of attacking the little busy bee, because I have attempted to show that it does not possess all the high qualities which have been popularly and poetically ascribed to it. But if scientific observations do not altogether support this intellectual eminence, which has been ascribed to bees, they have made known to us in the economy of the hive many curious peculiarities which no poet had ever dreamt of, and have shown that bees and other insects have an importance as regards flowers which had been previously unsu;pected. To them we owe the beauties of our gardens, the sweetness of our fields. To them flowers are indebted for their scent and colour, nay, their very existence in its present form. Not only have the brilliant colours, the sweet scent, and the honey of flowers been gradually developed by the unconscious selection of insects, but the very arrangement of the colours; the circular bands and radiating lines, the form, size, and position of the petals, the arrangement of the stamens and pistil, are all arranged with reference to the visits of insects, and in such a manner as to ensure the grand cbject which renders these visits necessary.

Thus, then, I have attempted to point out some of the rela tions which exist between insects and our common wild flowers the whole subject is one, however, which will repay most careful attention, for, as Miiller has truly said, there is no single species the whole history of which is yet by any means thoroughly known to us, and while, with reference to the regions of thought brought before us by the president on Wednesday evening, few can hope themselve; to assist in the progress of truth, the case is very different with reference to my subject of this evening, in which every one of us by care and perseverance may fairly hope to add something to the sum of human knowledge.

\section{NOTES}

WE hear that it is most probable that Dr. T. Lauder Brunton, F.R.S., whose investigations in the science of therapeutics have made him so well known to physiologists and pathologists generally, will undertake the editorship of the Practitioner, rentered vacant by the death of Dr. Anstie.

THE forty-seventh congress of German naturalists aud physicists opened at Breslau on Sept. I8. The proceedings were opened by the eminent chemist, Prof. Loewig, who expressed his satisfaction at seeing so many foreigners, whose presence in that assembly, he added, was a living testimony to the truth that science was of no country. Capt. von Dechen read a paper upon the present state and the future prospects of geolozy. After him, Prof. Virchow, of Berlin, spoke upon miracles re. garded from the scientific standpoint. The several sections were then constituted, and the members of the congress afterwarls adjourned to a banquet. In the evening an open-air entertainment was given by the city, and a telegraphic greeting was sent to the Emperor.

The fortieth congress of the French Institute of the Provinces, Les Mondes informs us, opened at Rodez on Monday last, under the presidency of M. de Toulouse-Lautrec, and will last ten days. There are five sections, in which questions are discussed connected with the mathematical, physical, and natural sciences, agriculture, inclustry and commerce, anthropology and the medical sciences, history and archrology, philosophy, literature, the fine arts, and social economy. This is certainly comprehensive enough.

THE last expedition for observing the transit of Venus is now on the point of leaving England for Egypt. It has developed into one of considerably greater magnitude than was at first intended. The Government expedition organised by Sir George Airy, instead of being located at Alexandria, will have its head. quarters at Cairo, the longitude of which city is to be found by exchange of telegraph signals with Greenwich, for which purpose a branch station will be established for a time at Alexandria: For the actual observation of the transit, Cairo, Thebes, and Suez are selected, the longitude of the last two being obtained by exchanging telegraph signals with Cairo. The photographic branch of the enterprise will probably be at Thebes. Private expeditions have been organised, all of them in concert with the English: Government one. The whole may be enumerated as follows :English Government Expedition.-Chief captain, C. Orcle Browne ; photogxaphic branch, Capt. Abney; astronomers, Mr. S. Hunter and Mr. Newton. Prof. Döllen, the Russian astronomer, and Col. Campbell have organised private expeditions to Thebes. Dr. Anvers proposes to be either at Cairo or Thebes, and Admiral Ommanney may also join the English party as an associate astronomer. The whole of the telescopes and. huts from Greenwich are now on board the Peninsular and Oriental vessel Hindosian, which is to leave Southampton on the ist proximo. 